Volume 5

Issue 2 Reducing Discrimination in the

Workplace

2019

\title{
Framing Matters: The Influence of Group-Image Threat on Reactions To Affirmative Action Policies
}

Kisha S. Jones

Pennsylvania State University

Anuradha Anantharaman

Pennsylvania State University

Anjali Bhatt

The Vanguard Group

Follow this and additional works at: https://scholarworks.bgsu.edu/pad

Part of the Human Resources Management Commons, Industrial and Organizational Psychology Commons, Organizational Behavior and Theory Commons, and the Social Psychology Commons How does access to this work benefit you? Let us know!

\section{Recommended Citation}

Jones, Kisha S.; Anantharaman, Anuradha; and Bhatt, Anjali (2019) "Framing Matters: The Influence of Group-Image Threat on Reactions To Affirmative Action Policies," Personnel Assessment and Decisions: Number 5 : Iss. 2 , Article 9.

DOI: https://doi.org/10.25035/pad.2019.02.009

Available at: https://scholarworks.bgsu.edu/pad/vol5/iss2/9

This Main Article is brought to you for free and open access by the Journals at ScholarWorks@BGSU. It has been accepted for inclusion in Personnel Assessment and Decisions by an authorized editor of ScholarWorks@BGSU. 


\title{
Framing Matters: The Influence of Group- Image Threat on Reactions To Affirmative ACtION Policies
}

\author{
Kisha S. Jones ${ }^{1}$, Anuradha Anantharaman', and Anjali Bhatt ${ }^{2}$
}

1. Pennsylvania State University

2. The Vanguard Group

\section{KEYWORDS}

affirmative action, groupimage threat, White identity management, diversity
ABSTRACT

Affirmative action (AA) attempts to rectify the institutional effects of prior employment discrimination toward minority groups. Although AA has played a large role in increasing workplace diversity, organizations may vary in their perspectives towards diversity itself, ranging from a sole focus on increasing diversity to appreciating the value diversity may add. Support for AA has been considered as a form of White identity management (Knowles, Lowery, Chow, \& Unzueta, 2014) and is impacted by the extent to which White people experience group-image threat to their racial identity. Our findings suggest that the level of group-image threat experienced by White people impacts both their organizational trust and AA policy attitudes depending on whether the policy rationale was framed around rectifying past discrimination or highlighting the importance of diversity to the organization. These results have implications for how organizations can attract, maintain, and develop a workforce with White employees who value and support diversity.
Affirmative action (AA) programs are one of many diversity practices an organization can utilize to reduce employment discrimination and increase diversity. Nishii, Khattab, Shemla, and Paluch's (2018) process model of diversity practice effectiveness describes how perceptions of diversity practices drive cognitions and attitudes employees have about these practices. These perceptions subsequently impact behavioral reactions (e.g., training attendance, disclosure, absenteeism) and ultimately organizational outcomes (e.g., managerial diversity, discrimination lawsuits, performance). This model further discusses the moderating role of personal relevance, or a "what's in it for me" rationale, between the use of diversity practices and perceptions of the practices. This suggests that support of AA policies among an organization's workforce, including nonbeneficiaries such as White Americans, is essential in order for ideal outcomes to be achieved. Unfortunately, the disadvantage nonbeneficiaries perceive themselves to have in hiring contexts that employ AA policies can lead to their negative reactions toward AA programs, especially with policies that are preferential towards minority groups (Kravitz, 2008).

The way in which AA policies are framed may mitigate negative reactions from nonbeneficiaries by shaping policy descriptions to deemphasize the potential disadvantages nonbeneficiaries may experience (Hideg \& Ferris, 2014; Lowery, Unzueta, Knowles, \& Goff, 2006). There is both conceptual and empirical support for distinct diversity management approaches that organizations can take, including some that solely focus on eliminating discrimination and promoting fairness in hiring practices and others that promote synergy, or the need to express, learn from, and integrate ideas of all employees irrespective of their background (Dwertmann, Nishii, \& van Knippenberg, 2016; Ely \& Thomas, 2001). Given the importance of diversity program support among an organization's workforce (Nishii et al., 2018), the role of diversity perspective framing in understanding nonbeneficiary reactions is important to consider.

The presence of negative attitudes towards AA among nonbeneficiaries is driven by factors such as racial attitudes and belief in discrimination towards minority groups (Harrison, Kravitz, Mayer, Leslie, \& Lev-Arey, 2006). This sug-

Corresponding author:

Kisha S. Jones

141 Moore Building, University Park, Pennsylvania, USA 16802

Email: kisha.jones@psu.edu 
gests that the viewpoint White Americans have around how race has historically impacted the opportunities of racial minority groups plays a key role in their reactions to AA. We therefore draw on Knowles, Lowery, Chow, and Unzueta's (2014) model of White identity management to incorporate group-image threat, which refers to self-identifying as a member of a group that is at fault for past or current harm against an outgroup. In the current study, we integrate research on diversity climate, AA policy framing, and White identity management to further understand how to increase AA support among White nonbeneficiaries. Understanding group-image threat can help inform recommendations made to organizations in their attempts to attract, retain, and develop employees who will foster inclusive climates with reduced discrimination.

\section{Literature Review and Hypotheses}

\section{AA and White Identity Management}

AA involves an organization devoting its resources toward efforts that ensure discrimination does not occur based on minority status (Crosby, Iyer, Clayton, \& Downing, 2003). AA programs are commonly thought to solely involve the hiring of unqualified minority group members over qualified majority group members (i.e., strong preferential treatment; this form of AA is illegal in employment settings). In most cases, however, they are implemented in weaker forms such as opportunity enhancement (e.g., targeting recruitment efforts towards minority groups), equal opportunity (e.g., prohibiting discrimination based on group membership), and weak preferential treatment (e.g., giving additional weight to minority status when deciding among equally qualified candidates; Kovach, Kravitz, \& Hughes, 2004). Therefore, AA policies can vary in strength, or prescriptiveness, with attitudes towards AA policies decreasing the more a person's minority status is considered (Harrison et al., 2006).

Ideally, nonbeneficiaries would recognize the value of diversity and how AA can assist in working towards a diverse and inclusive organizational workforce. Yet, predictors of AA attitudes among nonbeneficiaries suggest that White people who oppose AA focus on perceived unfair advantages received by racial minorities and ignore the pervasive societal benefits received by White people in the U.S. (Harrison et al., 2006; Shteynberg, Leslie, Knight, \& Mayer, 2011). Knowles and colleagues (2014) address this process through their White identity management model. This model outlines the ways in which White Americans avoid thoughts around their Whiteness in order to self-protect from threats that question the amount of hard work involved in their achievements (i.e., meritocratic threat) and make the wrongdoings of their racial group salient (i.e., group-image threat). Further, the model describes how these threats impact how White people subsequently manage their racial identity. The three identity management strategies provided in the model are denying White privilege, distancing oneself from one's Whiteness, and dismantling systems of inequality. We focus on the last strategy as it is directly determined by the extent to which group-image threat is perceived and is often represented through support for AA policies (Knowles et al., 2014).

Group-image threat often exists because people's self-concepts are connected to their group membership, with people generally wanting to feel positive about their ingroup. If, however, one is a member of a group responsible for past and present moral offenses toward outgroup members, the maintenance of positive ingroup attitudes may be difficult (Knowles et al., 2014). Research on White guilt, a form of group-image threat (Powell, Branscombe, \& Schmitt, 2005), has revealed its positive relationships with recognition of White privilege, acknowledgment of discrimination against Black people, and attitudes toward $\mathrm{AA}$, as well as its negative relationships with modern racism, subtle derogatory beliefs, and conservative political beliefs (Swim \& Miller, 1999). If one wants to deal with a group-image threat such as guilt, it would be necessary to endorse policies and initiatives that work to reduce his/her privilege, thereby restoring the reputation of oneself and his/her group (Knowles et al., 2014). Overall, this demonstrates the positive relationship between group-image threat and support for AA policies.

\section{AA and Diversity Management}

Importantly, AA policies are only effective when implemented within a well-functioning diversity management system (Kalev, Kelly, \& Dobbin, 2006). Unfortunately, it is possible for organizations to fail to value and appreciate the benefits of diversity. For instance, an organization may only attempt to address past discrimination by focusing on increasing numeric diversity (Ely \& Thomas, 2001). In these sorts of organizations, the diversity climate may be negative due to reduced appreciation for how diversity can be beneficial. Members of minority groups may feel devalued by their organization and intergroup conflict may stem from employees' lack of ability to discuss the status, power, and cultural differences that impact the experiences of minority group members at work (Ely \& Thomas, 2001).

A better approach towards managing diversity, however, reflects a recognition of the ways diverse perspectives can be utilized to achieve company goals. In this case, organizations demonstrate a value for diverse talent in several ways, including expressing a clear commitment to diversity, holding managers accountable for diversity goals, and implementing a work environment where employees from all backgrounds are encouraged to share their ideas (Dwertmann et al., 2016). In these organizations, employees believe in and support a value for diversity, and the trust built among employees and leaders across racial groups creates a 
comfort around discussing differences and working through conflict.

Applying signaling theory, which suggests that information from the sender is communicated to the receiver to reduce information asymmetry (Connelly, Certo, Ireland, \& Reutzel, 2011), the organization's diversity perspective can be signaled to potential applicants through its framing of its race-based AA policies (i.e., AA policies that focus on race only) so as to provide information on how that organization views and manages diversity. Prior work exploring the effects of diversity perspective AA policy framing found that nonbeneficiaries (in this case men) reported lower levels of overall and performance-based self-image when the AA policy was framed as addressing past discrimination compared to valuing diversity, whereas women did not differ in their reactions to the two framings (Hideg \& Ferris, 2014). In other words, when the AA policy suggested unearned privilege in prior hiring systems, men experienced threat to their self-image. When considering how this framing might impact how White nonbeneficiaries alone respond to racebased AA policies (as opposed to comparing them to beneficiaries), group-image threat to their racial identity may play a role.

\section{Hypotheses}

Taken together, race-based AA policy framing reflecting an organization's diversity perspective is expected to influence the relationship between group-image threat and both attitudes towards those policies and trust towards the organization that uses them. A past discrimination framing more clearly highlights factors that would make White advantage and racial minority disadvantage more salient. Those who are lower in group-image threat would likely not see the past discrimination framing as threatening because they do not acknowledge their privilege, whereas those higher in group-image threat would see this framing as more threatening due to their awareness of their privilege (Knowles et al., 2014). Hence, we expect little difference between those lower and higher in group-image threat when this framing is used.

The diversity value framing, on the other hand, signals that an organization sees the importance of diversity. It appears to be a more genuine attempt towards addressing racial privilege compared to the past discrimination framing, which only signals an obligation to restore fairness. The greater amounts of negative racial attitudes and rejection of privilege among those lower in group-image threat (Swim \& Miller, 1999) suggests that they would not prefer an organization that appears to value diversity. Those higher in group-image threat, however, would see an organization presenting a diversity value AA policy framing as being more consistent with their identity management strategy of dismantling the system. Further, the framing would not highlight their group's role in perpetrating discrimination but just valuing diversity overall. Therefore, we expect that:

Hypothesis 1: AA policy framing will moderate the effect of group-image threat on AA policy attitudes. Specifically, when White people are presented with a past discrimination framing, the relationship between group-image threat and AA policy attitudes will be weaker than it would be with a diversity value framing.

Hypothesis 2: AA policy framing will moderate the effect of group-image threat on organizational trust. Specifically, when White people are presented with a past discrimination framing, the relationship between group-image threat and trust will be weaker than it would be with a diversity value framing.

\section{METHOD}

\section{Participants and Procedure}

Two hundred and sixty undergraduate students in an introductory psychology course at a U.S. public university participated in this study for course credit. After removing non-White participants $(N=73)$, those who declined to reveal their race $(N=2)$ and excluding White careless respondents $(N=24)$, there were 161 White students (male = 78 ; female $=83)$ in the final study sample. The participants ranged in age from 18 to $31(M=19.25, S D=1.5)$ and had an average of 1.68 years $(S D=.47)$ of work experience. Forty-eight percent of participants $(N=77)$ indicated that they currently were looking for internships or would be in the next 6 months.

Participants took this study online and believed the purpose of the study was to examine reactions to an AA policy for a student internship program at Smith \& Company (a fictitious organization). After consenting to the survey, participants first completed a measure of group-image threat that was concealed among 60 personality items to mask the purpose of the study. Thereafter, participants were randomly assigned to a past discrimination or diversity value AA policy condition. After reading the policy, participants reported their attitudes towards the AA policy and trust of the organization. All measures in this study utilized a 7-point Likert scale ranging from 1 (strongly disagree) to 7 (strongly agree).

\section{Manipulations}

Both manipulations were adapted from Hideg and Ferris (2014). The past discrimination AA policy highlighted that Smith \& Company wanted to address past discrimination and current inequality that led racial minorities to be underrepresented but made no mention of whether diversity was actually important or valued. In contrast, the diversity value AA policy emphasized the importance of diversity to the organization in its ability to obtain a talent- 
ed workforce and compete in a global marketplace but did not mention previous discrimination or bias against racial minorities in the hiring process. Both policies mentioned a desire to increase the number of racial minorities hired for the internship program and described weak preferential treatment in which racial minorities would receive preference over White applicants when their qualifications were equal. Consistent with Hideg and Ferris (2014), we focused on AA policies with weak preferential treatment because they represent the highest level of prescriptiveness that is legal in most countries. These policies, therefore, would be in most need of framing to improve non-beneficiaries' perceptions of them. It should be noted that this form of AA is recommended on a short-term basis for jobs within organizations where underrepresentation of certain groups is clear, with the goal of eventually attaining a mix of talent from all backgrounds (Kovach et al., 2004).

To determine the effectiveness of the manipulations, we asked participants to describe why they thought the company was implementing the AA policy. We coded these responses for any mention of valuing diversity as opposed to past discrimination and performed a chi-square test of independence to determine whether their responses matched their intended conditions. The relationship between the condition and manipulation check code was statistically significant, $X^{2}(1, N=161)=18.71, p<.01$, suggesting that the manipulation was successful.

\section{Measures}

Group-image threat was measured using four items from Swim and Miller's (1999) White guilt scale $(\alpha=.85)$ : "Although I feel my behavior is typically nondiscriminatory towards Black people, I still feel guilt due to my association with the White race"; "I feel guilty about the benefits and privileges that I receive as a member of my racial/ ethnic group"; "When I learn about racism, I feel guilt due to my associations with the White race"; and "I feel guilty about the benefits and privileges that I receive as a White American." AA policy attitudes were assessed with 3 items adapted from Hideg, Michela, and Ferris (2011) to include Smith \& Company $(\alpha=.93)$ : "My opinion of developing an AA plan for racial minorities for Smith and Company's internship program is favorable"; "The proposed AA program is fair"; and "The potential benefits of the proposed AA program may outweigh the potential administrative costs." Organizational trust was measured using Purdie-Vaughns, Steele, Davies, Ditlmann, and Crosby's (2008) 11 item measure and was also modified to refer to Smith \& Company $(\alpha=.95)$. The items included: "I think I would trust the management to treat me fairly"; "I think that my values and the values of this company are very similar"; and "I think I would like to work under the supervision of people with similar values as the staff."

\section{RESULTS}

Descriptive statistics and correlations between study variables are presented in Table 1. The results of the hierarchical linear regression analyses used to test our hypotheses are presented in Table 2. For each regression analysis, gender was entered into the model as a control variable because women generally report higher levels of support for AA policies in comparison to men (Harrison et al., 2006). For all analyses, gender, AA policy, and group-image threat were entered at Step 1, with the interaction between AA policy and group-image threat included at Step 2. Continuous variables were centered before interaction terms were computed following Cohen, Cohen, West, and Aiken's (2003) procedures.

There was a statistically significant interaction between AA policy framing and group-image threat in predicting AA attitudes $(b=.36, p<.05)$ and is shown in Figure 1. Although the slopes of both lines are statistically significant, we see that the relationship between group-image threat and AA policy attitudes is weaker when the past discrimination framing is used $(b=.29, p<.01)$ and stronger when the diversity value framing is used $(b=.65, p<.001)$. In testing organizational trust as the dependent variable, the interaction between AA policy and group-image threat was also statistically significant $(b=.27, p<.05)$. In Figure 2, we see that the relationship between group-image threat and organizational trust is statistically significant when the diversity value framing is used $(b=.39, p<.001)$ but not when the past discrimination framing is used $(b=.12, n s)$. Overall, these findings provide support for both hypotheses.

\section{DISCUSSION}

\section{Theoretical Contributions}

Consistent with both hypotheses, our results show that the relationship between group-image threat and both trust and policy attitudes were stronger for the diversity value framing and weaker for the past discrimination framing. There was, however, a slight difference in the magnitude of how group-image threat influenced the outcome variables when the past discrimination framing was used. In particular, group-image threat had a positive impact on AA policy attitudes and no impact on organizational trust.

The past discrimination framing in our study highlighted racial minority disadvantage, making it necessary for those higher in group-image threat to support the policy to manage their White identities. However, it did not specifically mention White advantage, allowing those low in group-image threat to indicate more negative AA policy attitudes, and continuing the distance between themselves and their racial group privilege (Branscombe, Schmitt, \& Schiffhauer, 2007). Low identification with one's racial 
TABLE 1.

Descriptive Statistics and Correlations Between Study Variables

\begin{tabular}{lccccccc}
\hline Variable & $M$ & $S D$ & 1 & 2 & 3 & 4 & 5 \\
\hline 1. Gender & - & - & - & & & & \\
2. AA policy & - & - & .06 & - & & & \\
3. G-I threat & 3.78 & 1.41 & $.27^{*}$ & .01 & - & & \\
4. AA attitudes & 4.37 & 1.58 & .12 & -.02 & $.44^{*}$ & - & \\
5. Org. trust & 4.73 & 1.16 & .06 & .06 & $.33^{*}$ & $.70^{*}$ & - \\
\hline
\end{tabular}

Note. $N=161 . \mathrm{AA}=$ affirmative action. $\mathrm{G}-\mathrm{I}=$ group image. Gender is coded: male $=0$, female $=1$.

AA policy is coded: past discrimination AA framing $=0$, diversity value AA framing $=1 .{ }^{*} p<.01$.

TABLE 2.

Hierarchical Regression Results for AA Policy Framing and Group-Image Threat in Predicting AA Policy Attitudes and Organizational Trust

\begin{tabular}{lcccc}
\hline & \multicolumn{2}{c}{ AA attitudes } & \multicolumn{2}{c}{ Organizational trust } \\
\hline Variable & Step 1 & Step 2 & Step 1 & Step 2 \\
\hline Constant & $b$ & $b$ & $b$ & $b$ \\
Gender & $2.74^{* * *}$ & $3.38^{* * *}$ & $3.78^{* * *}$ & $4.25^{* * *}$ \\
AA policy & .05 & -.02 & -.04 & -.09 \\
G-I threat & -.08 & -.03 & .14 & .18 \\
AA $\times$ & $.45^{* * *}$ & $.29^{* *}$ & $.25^{* * *}$ & .12 \\
threat & & & & \\
$F$ & $11.33^{* * *}$ & $10.04^{* * *}$ & & $.27^{*}$ \\
$d f$ & 3 & 4 & $5.61^{* *}$ & $5.52^{* * *}$ \\
$R^{2}$ & .18 & .20 & 3 & 4 \\
Adjusted $R^{2}$ & .16 & .18 & .097 & .12 \\
$\Delta R^{2}$ & & $.03^{*}$ & .08 & .10 \\
\hline
\end{tabular}

Note. $N=161 . \mathrm{AA}=$ affirmative action. $\mathrm{G}-\mathrm{I}=$ group image. Gender is coded: male $=0$, Female $=1$.

AA policy is coded: past discrimination AA framing $=0$, diversity value AA framing $=1 .{ }^{* * *} p<.001$, $* * p<.01, * p<.05$.

group is consistent with colorblindness (Knowles et al., 2014), which helps explain why the relationship between group-image threat and AA policy attitudes was weaker for the past discrimination framing than the diversity value framing. Because those lower in group-image threat do not emphasize their own race, they would prefer a policy that signals an organization's multicultural philosophy and ap- preciation of racial group differences much less than those higher in group-image threat.

Further, the positive relationship between group-image threat and organizational trust with the diversity framing and nil relationship with the past discrimination framing can be explained using similar reasons. An organization that signals its value for diversity and appears to foster a 
FIGURE 1.

Moderating Effect of AA Policy Framing on the Relationship Between Group-Image Threat and Attitudes

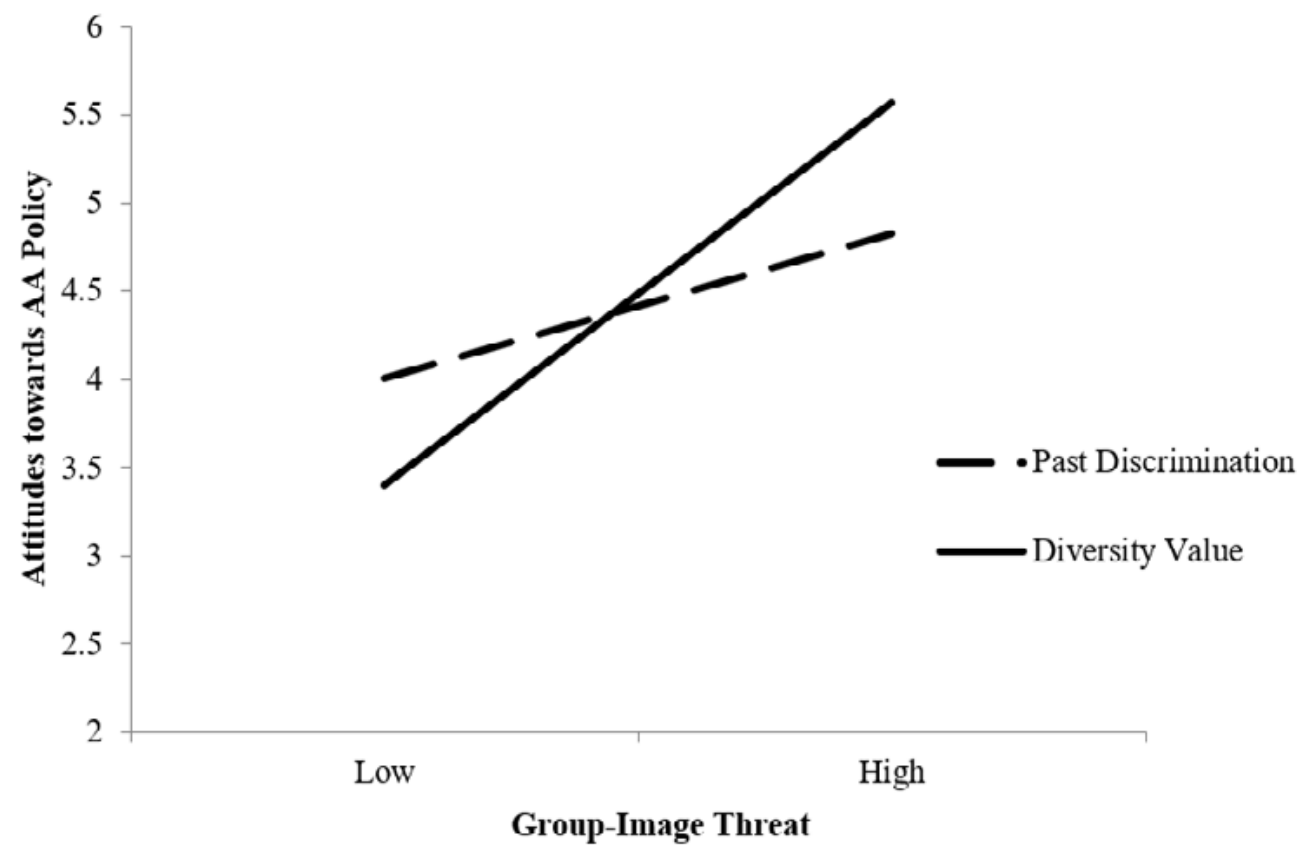

FIGURE 2.

Moderating Effect of AA Policy Framing on the Relationship Between Group-Image Threat and Organizational Trust

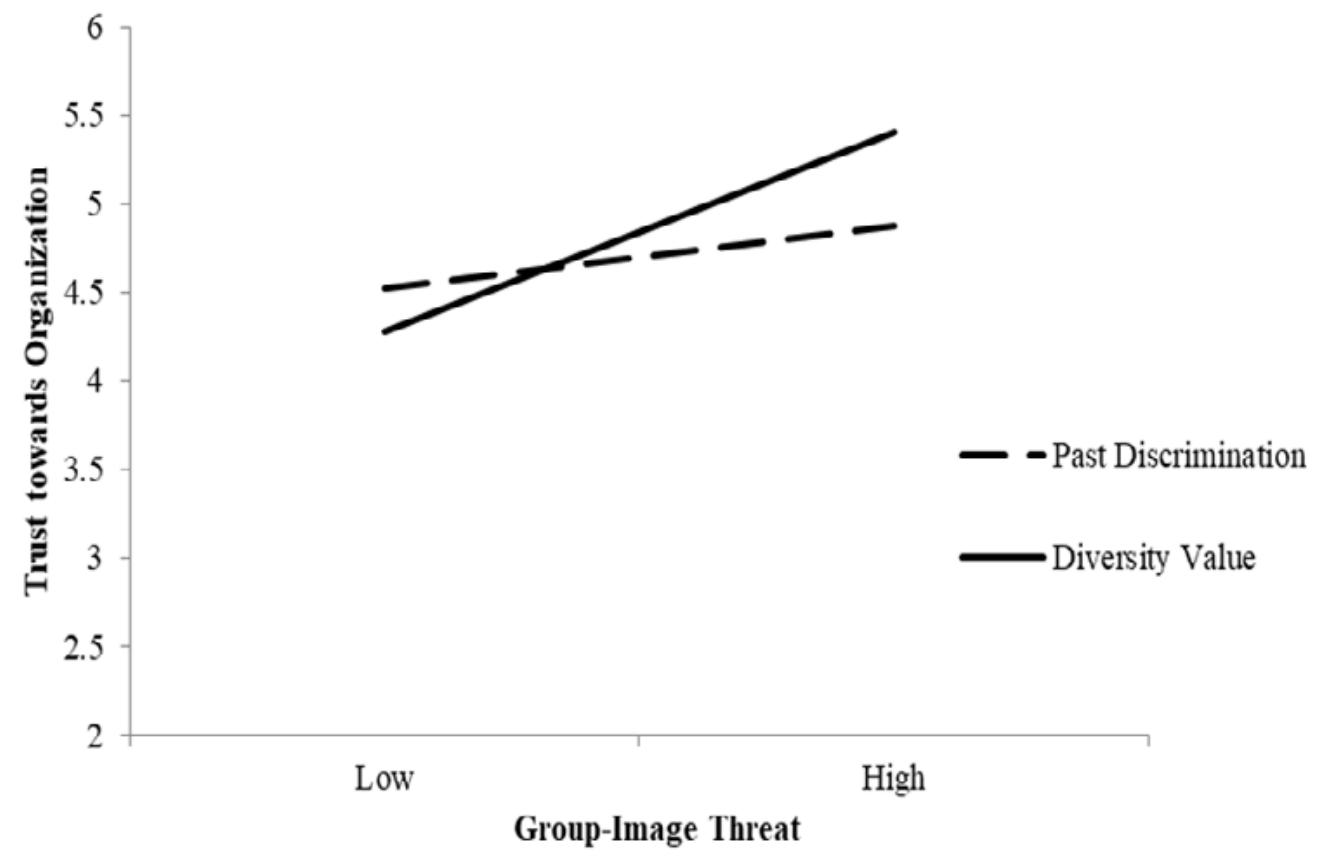


diversity climate that allows for full support of cultural differences (Ely \& Thomas, 2001) would be perceived as more trustworthy to those higher but not lower in group-image threat. On the other hand, an organization that signals that it is just focused on remediating past discrimination would provoke threat among those higher in group-image threat and indifference among those lower in group-image threat, leading to their similar levels of trust.

A note on high group-image threat. The negative effects of not recognizing racial privilege among Whites low in group-image threat is clear (Knowles et al., 2014). On the other hand, although White people high in group-image threat recognize White privilege, acknowledge discrimination towards racial minorities, and support AA policies (Swim \& Miller, 1999), it is important to note that the group-image threat resulting from realization of privilege is not ideal. It is fairly common for White Americans to not have fully developed their White racial identity and reckoned with the psychological costs that come with dominant racial-group membership in the U.S. (Goren \& Plaut, 2014). Therefore, those who do recognize their privilege but have not processed their racial identity would need threats toward their group image to drive their support of AA policies.

Group-image threat, particularly in the form of guilt, is self-focused and reveals a selfish motive of supporting AA in order to make one's group look better. Guilt would not, however, necessarily have long term effects, as it is not frequently experienced and can be avoided (Iyer, Leach, \& Pedersen, 2004). Ideally, the reason a White person would develop his/ her racial identity, accept how White privilege affects him/ herself and others, and subsequently value diversity and support AA policies would be because of a greater focus on helping those who are disadvantaged (as opposed to doing so to make the self feel better due to the prior behavior of one's group).

Iyer and colleagues (2004) discuss how sympathy and moral outrage are emotions that motivate action more effectively than guilt. Through sympathy, there would be genuine concern for the plight of disadvantaged groups, and through moral outrage, there would be more energy put towards blaming systems that supports White privilege for inequality. Therefore, White people high in group-image threat would perhaps be attracted to organizations that signal a value for diversity but may not be able to contribute effectively towards an inclusive climate on a consistent basis. Genuine empathy and perspective taking would be needed to develop authentic multicultural relationships (Goren \& Plaut, 2014). They would need to develop their racial identity and work towards feeling other-focused emotions when it comes to racial issues to be committed to social change for reasons beyond guilt.

\section{Practical Implications}

Knowledge of racial privilege and potential openness for social change are qualities organizations need in their workforce if they want to reduce race-based employment discrimination. Further, those who value diversity have been shown to engage in diversity promoting behaviors over time (Hiemstra, Derous, \& Born, 2017) and support other diversity initiatives such as diversity training (Nishii et al., 2018). This would overall shape the extent to which an organization is diverse and inclusive. Therefore, because those higher in group-image threat may be attracted to organizations that appear to value diversity (and frame their AA policies as such), organizations should be aware of this. With this knowledge, organizations can include diversity training content that help move White people higher in group-image threat away from more self-focused and toward other-focused collective perceptions that impact dismantling systems of oppression, including sympathy and moral outrage (Iyer et al., 2004). For instance, there is evidence suggesting that encouraging perspective taking during diversity training can increase motivation to reduce prejudice among those who are lower in empathy (Lindsey, King, Hebl, \& Levine, 2015). This would also allow for a better implementation of multicultural models that attempt to integrate White people (e.g., all-inclusive multiculturalism; Stevens, Plaut, \& Sanchez-Burks, 2008).

\section{Limitations and Future Directions}

One major limitation of the study is that we used a sample of college students with only half of them seeking internships, as opposed to applicants reading about an AA policy for the actual company to which they are applying. Future research might replicate this study among those actively seeking employment. It would also be useful to examine the impact of AA policy framing and group-image threat on actual application behavior, job acceptance, and engagement in inclusive workplace behaviors over time. In addition, prior research on AA policy attitudes has found strong effects based on the prescriptiveness of the AA policy, with policy attitudes decreasing as policy prescriptiveness increases (especially among nonbeneficiaries; Harrison et al., 2006). Given that our diversity perspective framing conditions both used weak preferential treatment and resulted in no main effect of framing on either outcome, future work on non-beneficiaries should examine diversity perspective framing across different levels of AA policy prescriptiveness. Building on prior work indicating the effectiveness of framings that address multiple rationales for implementing AA policies (e.g., highlighting both past discrimination and benefits to majority and minority groups; Knight \& Hebl, 2005), it would be useful to replicate our study with a condition that combines both past discrimination and diversity value framings. 
Finally, another limitation concerns how a low group-image threat score could be interpreted. Consistent with our hypotheses, a White person may have low levels of guilt because $\mathrm{s} / \mathrm{he}$ has not dealt with White privilege and would subsequently not be as supportive of AA policies and/or value diversity. Conversely, there may be White people who have low levels of guilt and support AA policies and diversity. In this case, a White person likely understands his/her privilege and therefore does not experience group-image threat. In this case, s/he would not be focused on the role of self in his/her group's history but instead focused on the other group (Iyer et al., 2004). Future research could replicate this study while accounting for sympathy and moral outrage, as well as White privilege perceptions and racial identity development.

To obtain the desired outcomes of diversity initiatives such as reduced discrimination and increased inclusion, organizations must have support from its entire workforce (Nishii et al., 2018). Because support for race-based AA policies among nonbeneficiaries is generally lower, efforts to explore reactions to AA policy framings are especially useful. We identified that framing AA policies based on organizational diversity perspectives moderates how group-image threat influences reactions among White people. In knowing now that diversity value AA policy framings are viewed positively by White Americans higher in group-image threat, organizations that want to develop and maintain inclusive climates can help support them in moving away from feelings of group-image threat towards genuine desires for equality and inclusion.

\section{REFERENCES}

Branscombe, N. R., Schmitt, M. T., \& Schiffhauer, K. (2007). Racial attitudes in response to thoughts of White privilege. European Journal of Social Psychology, 37, 203-215. doi: 10.1002/ejsp.348

Cohen, J., Cohen, P., West, S. G., \& Aiken L. S. (2003). Applied multiple regression/correlation analysis for the behavioral sciences. (3rd ed.) Mahwah, NJ: Lawrence Erlbaum.

Connelly, B. L., Certo, S. T., Ireland, R. D., \& Reutzel, C. R. (2011). Signaling theory: A review and assessment. Journal of Management, 37, 39-67. doi: 10.1177/0149206310388419

Crosby, F. J., lyer, A., Clayton, S., \& Downing, R. A. (2003). Affirmative action: Psychological data and policy debates. American Psychologist, 58, 93-115. doi: 10.1037/0003066X.58.2.93.

Dwertmann, D. J., Nishii, L. H., \& van Knippenberg, D. (2016). Disentangling the fairness \& discrimination and synergy perspectives on diversity climate: Moving the field forward. Journal of Management, 42, 1136-1168. doi: $10.1177 / 0149206316630380$

Ely, R. J., \& Thomas, D. A. (2001). Cultural diversity at work: The effects of perspectives on work group processes and out- comes. Administrative Science Quarterly, 46, 229-273. doi: $10.2307 / 2667087$

Goren, M. J., \& Plaut, V. C. (2014). Racial identity denial and its discontents: Implications for individuals and organizations. In K. M. Thomas, V. C. Plaut, \& N. M. Tran (Eds.), Diversity ideologies in organizations (pp. 43-66). New York, NY: Routledge.

Harrison, D. A., Kravitz, D. A., Mayer, D. M., Leslie, L. M., \& Lev-Arey, D. (2006). Understanding attitudes toward affirmative action programs in employment: Summary and meta-analysis of 35 years of research. Journal of Applied Psychology, 91, 1013-1036. doi: 10.1037/0021-9010.91.5.1013

Hideg, I., \& Ferris, D. L. (2014). Support for employment equity policies: A self-enhancement approach. Organizational Behavior and Human Decision Processes, 123, 49-64. doi: 10.1016/j.obhdp.2013.11.002

Hideg, I., Michela, J. L., \& Ferris, D. L. (2011). Overcoming negative reactions of nonbeneficiaries to employment equity: The effect of participation in policy formulation. Journal of Applied Psychology, 96, 363-376. doi: 10.1037/a0020969

Hiemstra, A. M. F., Derous, E., \& Born, M. P. (2017). Psychological predictors of cultural diversity support at work. Cultural Diversity and Ethnic Minority Psychology, 23, 312-322. doi: 10.1037/cdp0000141

lyer, A., Leach, W. C., \& Pedersen, A. (2004). Racial wrongs and restitutions: The role of guilt and other group-based emotions. In M. Fine, L. P. Pruitt, \& A. Burns (Eds.), Off white: Readings on power, privilege, and resistance, (pp. 345-361). New York, NY: Routledge.

Kalev, A., Kelly, E., \& Dobbin, F. (2006). Best practices or best guesses? Assessing the efficacy of corporate affirmative action and diversity policies. American Sociological Review, 71, 589-617. doi: 10.1177/000312240607100404

Knight, J. L., \& Hebl, M. R. (2005). Affirmative reaction: The influence of type of justification on nonbeneficiary attitudes toward affirmative action plans in higher education. Journal of Social Issues, 61, 547-568. doi: 10.1111/j.15404560.2005.00420.x

Knowles, E. D., Lowery, B. S., Chow, R. M., \& Unzueta, M. M. (2014). Deny, distance, or dismantle? How White Americans manage a privileged identity. Perspectives of Psychological Science, 9, 594-609. doi: 10.1177/1745691614554658

Kovach, K. A., Kravitz, D. A., \& Hughes, A. A. (2004). Affirmative action: How can we be so lost when we don't even know where we are going? Labor Law Journal, 55, 53-61.

Kravitz, D. A. (2008). The diversity-validity dilemma: Beyond selection-the role of affirmative action. Personnel Psychology, 61, 173-193. doi: 10.1111/j.1744-6570.2008.00110.x

Lindsey, A., King, E., Hebl, M., \& Levine, N. (2015). The impact of method, motivation, and empathy on diversity training effectiveness. Journal of Business and Psychology, 30, 605617. doi: $10.1007 / \mathrm{s} 10869-014-9384-3$

Lowery, B. S., Unzueta, M. M., Knowles, E. D., \& Goff, P. A. (2006). Concern for the in-group and opposition to affirmative action. Journal of Personality and Social Psychology, 90, 961-974. doi: 10.1037/0022-3514.90.6.961

Nishii, L. H., Khattab, J., Shemla, M., \& Paluch, R. M. (2018). A multi-level process model for understanding diversity practice effectiveness. Academy of Management Annals, 12, 3782. doi: 10.5465/annals.2016.0044 
Powell, A. A., Branscombe, N. R., \& Schmitt, M. T. (2005). Inequality as ingroup privilege or outgroup disadvantage: The impact of group focus on collective guilt and interracial attitudes. Personality and Social Psychology Bulletin, 31, 508521. doi: $10.1177 / 0146167204271713$

Purdie-Vaughns, V., Steele, C. M., Davies, P. G., Ditlmann, R., Crosby, J. R. (2008). Social identity contingencies: How diversity cues signal threat or safety for African Americans in mainstream institutions. Journal of Personality and Social Psychology, 94, 615-630. doi: 10.1037/0022-3514.94.4.615

Shteynberg, G., Leslie, L. M., Knight, A. P., \& Mayer, D. M. (2011). But affirmative action hurts us! Race-related beliefs shape perceptions of White disadvantage and policy unfairness. Organizational Behavior and Human Decision Processes, 115, 1-12. doi: 10.1016/j.obhdp.2010.11.011

Stevens, F. G., Plaut, V. C., \& Sanchez-Burks, J. (2008). Unlocking the benefits of diversity: All-inclusive multiculturalism and positive organizational change. Journal of Applied Behavioral Science, 44, 116-133. doi:10.1177/0021886308314460

Swim, J. K., \& Miller, D. L. (1999). White guilt: Its antecedents and consequences for attitudes towards affirmative action. Personality and Social Psychology Bulletin, 25, 500-514. doi: $10.1177 / 0146167299025004008$

RECEIVED 06/01/18 ACCEPTED 01/30/19 